Sains Malaysiana 50(11)(2021): 3321-3332

http://doi.org/10.17576/jsm-2021-5011-16

\title{
Association of Serum Vitamin D Level and Vitamin D Receptor Expression among Newly Diagnosed Breast Cancer
}

(Hubungan antara Tahap Serum Vitamin D dan Pengekspresan Reseptor Vitamin D dalam Kalangan Pesakit Kanser Payudara Baharu Didiagnos)

\author{
Hani Ajrina Zulkeflee, Tuan Salwani Tuan Ismail*, Tengku Ahmad Damitri Al-Astani Tengku Din, \\ MAYA MAZUWIN YAHYA \& WAN FAIZIAH WAN ABDUL RAHMAN
}

\section{ABSTRACT}

There is a mushrooming interest in the anti-carcinogenic property of vitamin D. However, many researches reported a conflicting result in the association of vitamin D levels to certain types of cancer. This study was designed to assess the association between vitamin D and vitamin D receptor (VDR) expression with breast cancer. This case-control study, carried out at Hospital Universiti Sains Malaysia, Kelantan, involved 69 newly diagnosed breast cancer patients and 73 healthy volunteers. Serum 25(OH)D was taken and compared between 2 groups. VDR expression in patients'breast tissue samples was determined by immunohistochemical staining method using anti-VDR antibody. 85.5\% of breast cancer patients and $97.3 \%$ of healthy control were vitamin D insufficient with a mean (SD) of $13.36(6.96) \mathrm{ng} / \mathrm{mL}$ and 13.05 (3.71) $\mathrm{ng} / \mathrm{mL}$, respectively, and the difference was not statistically significant. VDR expression showed cytoplasmic positivity in $75.4 \%$ of breast cancer tissue, followed by both cytoplasmic and nuclear positivity in $21.5 \%$ and complete absence in 3\%. There was no significant association between VDR expression and hormone receptor status. In conclusion, there was a high prevalence of vitamin D deficiency among breast cancer and healthy volunteers in our study. There was no significant association between breast cancer and vitamin D. The VDR expression in breast cancer cells showed high cytoplasmic localization.

Keywords: Breast cancer; prognosis; risk; vitamin D; vitamin D receptor expression

\section{ABSTRAK}

Dewasa ini, kajian mengenai sifat anti-kanser pada vitamin D semakin meluas. Namun demikian, banyak kajian mengenai hubungan antara tahap vitamin D dan jenis-jenis kanser melaporkan keputusan yang berbeza. Oleh itu, kajian ini dijalankan untuk menilai hubungan antara tahap vitamin D dan reseptor vitamin D (VDR) dengan kanser payudara. Kajian kes kawalan ini telah dijalankan di Hospital Universiti Sains Malaysia (HUSM), Kelantan, yang melibatkan 69 pesakit yang baru disahkan menghidapi kanser payudara dan 73 orang sukarelawan yang sihat. Serum 25(OH)D telah diambil dan bacaannya dibandingkan antara 2 kumpulan. Pengekspresan VDR dalam sampel tisu payudara pesakit ditentukan melalui teknik imunohistokimia menggunakan antibodi anti-VDR. 85.5\% daripada pesakit kanser payudara dan 97.3\% sukarelawan mempunyai kekurangan vitamin D dengan purata (SD) dalam kalangan pesakit adalah 13.36 (6.96) $\mathrm{ng} / \mathrm{mL}$ dan dalam kalangan sukarelawan adalah 13.05 (3.71) $\mathrm{ng} / \mathrm{mL}$. Perbezaan tahap vitamin $D$ dalam kalangan pesakit dan sukarelawan tidak signifikan dari segi statistik. 50.7\% daripada tisu kanser payudara merupakan VDR positif. Pengekspresan VDR wujud dalam 75.4\% sitoplasma sel kanser payudara, 21.5\% pada sitoplasma dan nukleus dan 3\% tidak wujud pada sel kanser. Kajian ini tidak menunjukkan sebarang hubungan yang signifikan antara pengekspresan VDR dan status reseptor hormon. Kesimpulannya, kajian ini melaporkan kekurangan vitamin D yang tinggi dalam kalangan pesakit kanser payudara dan sukarelawan. Tiada hubungan yang signifikan antara kanser payudara dan tahap vitamin D. Pengekspresan VDR pada sel kanser payudara menunjukkan penyetempatan sitoplasma yang tinggi.

Kata kunci: Kanser payudara; pengekspresan reseptor vitamin D; prognosis; risiko; vitamin D

\section{INTRODUCTION}

About $32.1 \%$ of malignancies affecting Malaysian women are due to breast cancer (Nor Saleh \& Noor
Hashima 2016). Advanced age, prolonged exposure to estrogen, first degree relatives with breast cancer and previous benign breast disease are among the established 
risk factors for breast cancer (Momenimovahed \& Salehiniya 2019). Despite advancements in medical intervention worldwide, the death of Malaysian women due to malignant breast neoplasm showed increment from $3.8 \%$ in 2016 to $4.4 \%$ in 2017 (Statistics on Causes of Death, Malaysia 2018). Thus, further recognition and prevention of modifiable risk factors should be promoted to improve the breast cancer incidence rate.

Vitamin D is a fat-soluble vitamin responsible for maintaining calcium homeostasis and bone remodeling. Currently, there is an increasing interest in the extraskeletal, anti-carcinogenic property of vitamin $\mathrm{D}$ as shown by the many studies on vitamin D levels and specific types of malignancy (Jacobs et al. 2016; Jeon \& Shin 2018). Experimental studies showed that calcitriol, the active form of vitamin $\mathrm{D}$, upon binding to the nuclear vitamin $\mathrm{D}$ receptor (VDR): controls the expression of genes involved in different functions e.g. BRCA1 gene expression; influences the production of RNA encoded for proteins essential for specific cancer tissue metabolism; induces cellular differentiation and apoptosis; and inhibits tumor cell growth, inflammatory process and vascular formation (Bandera Merchan et al. 2017; de La Puente-Yagüe et al. 2018; Jeon \& Shin 2018).

Upon diagnosis, breast cancer is classified into 5 molecular subtypes according to the presence of estrogen receptor (ER), progesterone receptor (PR), human epidermal growth factor receptor-2 (HER2), and Ki-67 (Kondov et al. 2018). In breast carcinogenesis particularly in estrogen-sensitive tumor, estrogen signaling may be disrupted by vitamin D and subsequently ceased the tumor proliferative activity.

In recent years, studies have supported the association between lower vitamin D levels with higher breast cancer risk. Furthermore, breast cancer patients with vitamin $\mathrm{D}$ deficiency are also susceptible to a poorer prognosis. Although Malaysia is a tropical country, receiving ample and consistent amount of sunlight all year round, there is still a high prevalence of vitamin $\mathrm{D}$ deficiency. Despite the high prevalence of vitamin D deficiency in Malaysia and malignant breast neoplasm is one of the common causes of death among Malaysian women, there is still limited data on the vitamin D status among breast cancer patients in Malaysia. Additionally, VDR expression in association with serum vitamin D level is another matter of debate. Therefore, this study aims to determine the serum vitamin $\mathrm{D}$ concentration and the VDR expression among breast cancer patients in Malaysia.

\section{MATERIALS AND METHODS}

\section{SUBJECTS}

This study was conducted at Hospital Universiti Sains Malaysia, Kubang Kerian, Kelantan, Malaysia. Study participants were recruited within one-year duration, from April 2018 to April 2019. The sample size was calculated using single proportion formula with the population proportion based on Jamila et al. (2017). The minimum sample size required for each case and control group was 73 participants based on case to control ratio of 1. A convenient sampling method was done for cases due to the expected limited number of patients in the study period. A voluntary sampling method was done via posters to recruit controls. Case and control were matched for the female sex.

All newly diagnosed breast cancer patients by histopathological examination (HPE) who had fulfilled the inclusion criteria were included in this study. Cases were identified among those attending Breast Cancer Awareness and Research Unit (BestaRi), HUSM. All patients included in this study were: 1) above 18 years of age, 2) diagnosed as primary breast cancer (i.e. nonrelapse), 3) regardless of tumor grading (i.e. locally invasive) and staging (i.e. metastasis) at time of diagnosis, and 4) treatment-naive. Patients who were male, had non-epithelial tumor in origin or prior history of other malignancy, had underlying chronic liver or kidney disease, chronic gastrointestinal upset (loose stool or diarrhea more than 3-months duration), history of gastric and small bowel resection or on drugs that may alter vitamin D concentration such as oral contraceptive pill, hormonal replacement therapy, vitamin D supplements, steroids, phenobarbital, and phenytoin were excluded from this study.

Healthy women volunteers aged 18 years and above with no palpable breast lump and no family history of breast cancer were recruited as a control group. Similar exclusion criteria were applied to this group. This study protocol was approved by the Human Research Ethics Committee USM (HREC) Code: USM/JEPeM/17110668 and all subjects provided written informed consent for their participation in the study.

\section{BIOCHEMICAL MEASUREMENTS}

Participants' peripheral blood were sampled a in $4 \mathrm{~mL}$ BD Vacutainer tube (Becton Dickinson, Franklin Lakes, USA) and were incubated at room temperature for 20-60 min to allow complete clot formation. Samples were then 
centrifuged at 3000 revolutions per minute (RPM) for 15 min and stored at $-80{ }^{\circ} \mathrm{C}$ freezer until analysis.

Serum 25(OH)D was measured by chemiluminescent competitive immunoassay principle on Access 2 Immunoassay System analyzer by Beckman Coulter. This method is traceable to the isotope dilution mass spectrometry (ID-LC-MS/MS) reference method procedure (RMP) developed by the National Institute for Standards and Technology (NIST), Ghent University and the Centers for Disease Control and Prevention (CDC), and approved by Joint Committee for Traceability in Laboratory Medicine (JCTLM) (Stepman et al. 2011; Thienpont et al. 2012; Wise \& Watters Jr. 2009). The assay coefficient variation was less than $2.2 \%$. The concentration of serum vitamin $\mathrm{D}$ was classified based on the recommendation by the United States National Academy of Medicine (NAM) as vitamin D insufficiency $(<20 \mathrm{ng} / \mathrm{mL})$ and vitamin D sufficiency $(\geq 20 \mathrm{ng} / \mathrm{mL})$.

\section{ESTROGEN RECEPTOR (ER), PROGESTERONE RECEPTOR (PR), AND HER2 STATUS}

The data on ER, PR, and HER2 status were obtained from the laboratory information system based on the report from respective pathologists in HUSM. The ER, PR, and HER2 status were determined by the immunohistochemical (IHC) staining method. The ER and PR positivity were accounted for by at least $1 \%$ of nuclear positivity by immunohistochemistry (Allred et al. 1990). The HER 2 expression by immunohistochemistry were divided into negative (score 0 or $1+$ ), equivocal (score $2+$ ), and positive (score $3+$ ). The equivocal HER2 result was confirmed by Dual-color-hapten brightfield in situ hybridization (DDISH). Absence of all ER, PR and HER2 were classified triple-negative status.

\section{VITAMIN D RECEPTOR EXPRESSION}

VDR expression was assayed using the IHC staining method with validated rabbit polyclonal anti-VDR antibody (Abcam, Ab3508). Patients' breast tissue samples were retrieved from the archives of the pathology laboratory. One selected paraffin block with a tumor was used for each patient, sectioned for $5 \mu \mathrm{m}$ in thickness on the rotary microtome. Sections were deparaffinized and rehydrated with descending grades of ethanol. Antigen retrieval was performed by heating the slides in a pressure cooker with citrate buffer $\mathrm{pH}$ 6.0. After that, endogenous peroxidase quenching with $3 \%$ hydrogen peroxide in methanol followed by Dako Protein block $(0.25 \%$ casein in phosphate-buffered saline). Then, the specimens were incubated overnight with 1:1000 dilutions of anti-
VDR antibody, washed and followed by incubation with secondary antibody. Colorimetric detection was completed with Diaminobenzidine chromogen. Slides were counterstained by haematoxylin and subsequently dehydrated with graded ethanol dilutions, cleared in xylene and mounted. Placenta tissue served as a positive control as used by other studies (Czogalla et al. 2020; Ditsch et al. 2012) and it is known to express VDR. Thus, it was used to indicate that the staining method is optimized. The tissue was obtained from the archives of the pathology laboratory. The ethical approval to use this placenta sample was obtained from Human Research Ethics Committee USM (HREC) Code: USM/JEPeM/17110668.

The slides were evaluated by two trained pathologists using a semi-quantitative Allred system of scoring (Iqbal \& Buch 2016). They were assessed according to intensity of staining (intensity score), as presented in Figure 1: (Score 0: negative, 1: weak, 2: intermediate, 3: strong) and proportion of cells which are stained (Proportion score 0 : No cells are positive, $1:<1 \%$ cells are positive, $2: 1-10$ $\%$ cells are positive, $3: 11-33 \%$ cells are positive, $4: 34$ - 66\% cells are positive, 5: 67 - 100\% cells are positive). The final Allred score was calculated by adding the proportion score and intensity score from 0 to 8 . The VDR expressions were classified into 2 - negative (Score 0 - 2) and positive (Score 3 - 8).

\section{STATISTICAL ANALYSIS}

Statistical analysis was performed using the Statistical Package for Social Science (SPSS) version 24 where p-value $\leq 0.05$ was accepted as significant for all statistical tests. Categorical variables were described as counts and percentages while numerical data were expressed as mean and standard deviation (SD) as they were normally distributed. Independent t-test was applied to study the association between serum $25(\mathrm{OH}) \mathrm{D}$ level between the case and control group as well as with the hormonal status of the breast cancer group. Chi-squared test was used to study the association of vitamin D status in cases and controls; and VDR expression status with hormonal receptor status. The association between VDR expression and staining localization was determined by using Fisher's exact test.

\section{RESULTS AND DISCUSSION}

\section{RESULTS}

A sample size of 69 cases and 73 controls were obtained within the study period. This is slightly lower than the required sample size of 73 cases based on a single 
proportion formula. The participants' demographic characteristics are illustrated in Table 1. The mean age of the case was 54.58 years old and was significantly older than the control, 32.71 years old $(\mathrm{P}<0.001)$.

The mean serum concentration of $25(\mathrm{OH}) \mathrm{D}$ of case and control groups was $13.36 \pm 6.98 \mathrm{ng} / \mathrm{mL}$ and $13.05 \pm 3.71 \mathrm{ng} / \mathrm{mL}$, respectively, but the difference was not statistically significant $(\mathrm{P}=0.74)$. Among the healthy control group, $97.3 \%$ had insufficient $(<20 \mathrm{ng} /$ $\mathrm{mL}$ ) concentration of serum $25(\mathrm{OH}) \mathrm{D}$ and only $2 \%$ were vitamin D sufficient $(\geq 20 \mathrm{ng} / \mathrm{mL})$ as shown in Table 2 . Similar findings were noted among breast cancer patients where $85.5 \%$ had insufficient vitamin D status and the remaining $14.5 \%$ were within the sufficient level. Among breast cancer patients, as presented in Table 3, the mean concentration of serum 25(OH)D was significantly lower in $\mathrm{ER}+$ and $\mathrm{PR}+$. However, there was no significant association found between serum 25(OH)D concentration and HER2/C-ERB2, triple-negative and VDR expression status.

VDR expression in adjacent normal breast tissue showed a cytoplasmic positivity as shown in Figure 1(F). Whereas, VDR expression in ductal carcinoma in situ (DCIS) component were variable and not much different from invasive malignant tumour. However, no separate scoring done only for DCIS but we were focusing on invasive tumour areas. There were cytoplasmic VDR positivity in $75.4 \%$ of breast cancer tissue, followed by both cytoplasmic and nuclear positivity in $21.5 \%$ of cases and complete absence of staining in 3\% of specimen. There was no significant association between VDR expression with ER, PR status, HER2/C-ERB2 and triple-negative status (Table 4).

\section{DISCUSSION}

The cutoff concentration for defining the stages of vitamin D status remains debatable. The United States National Academy of Medicine (NAM) defined insufficient vitamin D status when serum 25(OH)D level was between $12-20 \mathrm{ng} / \mathrm{mL}(30-50 \mathrm{nmol} / \mathrm{L})$, and vitamin $\mathrm{D}$ deficient when it was below $12 \mathrm{ng} / \mathrm{mL}(30 \mathrm{nmol} / \mathrm{L})$ (Ross et al. 2011). This was based on their report on a minimum serum $25(\mathrm{OH}) \mathrm{D}$ level of $20 \mathrm{ng} / \mathrm{mL}$ to obtain optimum bone health in the majority of the population. Alternatively, Endocrine society recommended a higher cutoff i.e. values less than $20 \mathrm{ng} / \mathrm{mL}(50 \mathrm{nmol} / \mathrm{L})$ were classified as vitamin $\mathrm{D}$ deficient, and those in between 20 - $29 \mathrm{ng} / \mathrm{mL}(50-72.5 \mathrm{nmol} / \mathrm{L})$ as vitamin D insufficient (Holick et al. 2011).

Given lack of consensus in serum 25(OH)D level in interpreting vitamin D status, the United
States National Institutes of Health (NIH) Office of Dietary Supplements (ODS) developed the Vitamin D Standardization Program (VDSP) to standardize the laboratory measurement of serum $25(\mathrm{OH}) \mathrm{D}$ level and classification of the stages of vitamin D status (Binkley et al. 2017). This protocol was an international initiative to produce accurate serum $25(\mathrm{OH}) \mathrm{D}$ result and traceable to the National Institute for Standards and Technology and Ghent reference method procedure. Most of the studies applying VDSP protocol used threshold as defined by NAM and thus $20 \mathrm{ng} / \mathrm{mL}(50 \mathrm{nmol} / \mathrm{L})$ was used as cut off in our study (Cashman et al. 2015).

From our case-control study, majority of the participants in both groups $(85.5 \%$ of breast cancer patients and $97.3 \%$ of healthy volunteers) were vitamin D insufficient with mean serum $25(\mathrm{OH})$ concentration (Case: $13.36 \mathrm{ng} / \mathrm{mL}$, Control: $13.05 \mathrm{ng} / \mathrm{mL}$ ) below the optimal level of vitamin D. This finding was in line with previous studies on vitamin D status among women in Malaysia. A study among 259 pregnant women in Seremban showed $91.5 \%$ had vitamin D deficient and $8.5 \%$ were vitamin D insufficient while none of them had sufficient vitamin D level (Lalitha et al. 2020). A cross sectional study among 770 female teachers in Kuala Lumpur reported a prevalence of more than $70 \%$ vitamin D deficiency ( $<20 \mathrm{ng} / \mathrm{mL}$ ) (Foong et al. 2017). An article review showed a worldwide pandemic of vitamin $\mathrm{D}$ deficiency and the majority of the cases were caused by inadequate sunlight exposure (Holick 2017). Our study was conducted in Kelantan where the majority of its population are Muslim Malays. Thus, a high prevalence of vitamin D insufficiency in this study might be attributed to the extensive clothing cover which is greatly influenced by religious and cultural beliefs. When sunlight exposure is limited, adequate vitamin D fortified food becomes the only source of vitamin D. However, there is still a lack of awareness among the Kelantan population to take vitamin supplements and vitamin D rich food.

While many studies showed an inverse relationship between serum 25(OH)D concentration and breast cancer risk and prognosis (Acevedo et al. 2016; O'Brien et al. 2017; Yao et al. 2017), our study reported no significant association between serum vitamin $\mathrm{D}$ level in case and control groups. Our data showed a slightly lower mean concentration of serum 25(OH)D in the control group. Although the control group was significantly younger than the case group, the age differences does not contribute to the variation in the serum 25(OH)D level according to literature (Deckers et al. 2013; dos Santos Ferreira et al. 2017; Waldhoer et al. 2018). In addition, 
majority of them were healthcare staff who spent more time indoors. This lack of sun exposure together with an improper diet may result in lower serum 25(OH)D concentration in controls than in cases. Studies reporting significant inverse association must be evaluated carefully because the timing of sample collection may affect the serum 25(OH)D level (Scarmo et al. 2013). For example, selected breast cancer patients in a cohort study among Chilean women were those who had already been treated with chemotherapy and initiated their hormonal therapy (Acevedo et al. 2016). Hence, the 25(OH)D levels in this study may be influenced by the progression of the disease, treatment and behavioral changes in response to the disease i.e. bed and home-bound, or loss of appetite. In an estrogen-sensitive tumor i.e. luminal-type breast cancer, deficiency in vitamin D level is associated with poor prognosis in luminal-type breast cancer. A few research and meta-analysis reviews reported an inverse relationship between vitamin D level and tumor staging especially in the manifestation of triple-negative status (de Sousa Almeida-Filho et al. 2017; Omalkhair et al. 2016; Yao et al. 2017). In our study, there is a significant association between serum $25(\mathrm{OH}) \mathrm{D}$ concentration with ER and PR status. However, no significant association was found between serum 25(OH)D concentration with HER2/C-ERB2 and triple-negative status.

The anti-tumorigenic effects of vitamin $\mathrm{D}$ are expressed when it binds to the VDR, a member of the nuclear receptor gene family. It is pertinent to accurately identify VDR in tissues to understand the pathophysiology of vitamin D in carcinogenesis. This could be fundamental to the development of an alternative therapeutic method targeting the VDR. It is present in many organs including the mammary gland (Pike et al. 2017). A recent study demonstrated that lower expression of VDR exhibited a higher risk for cancer and lack of its expression correlates with poorer prognostic values (Jamila et al. 2017; Soljic et al. 2018). However, our study reported no significant association between VDR expression with tumor subtype according to ER, PR status, HER2/C-ERB2, and triple-negative status. This is most probably due to a very small number of patients in each subgroup to demonstrate its association. Nevertheless, a similar finding was also observed in the analysis of VDR in circulating breast tumor cells (CTCs) - a surrogate tumor material (Zhang et al. 2017). Although it is currently enumerated for use as the tumor biomarker testing, its comparability to the primary tumor remains inconsistent. Studies among breast cancer patients showed that the agreement of ER and PR expression between CTCs and primary tumors varied widely ranging from 40 to 70\% (Aktas et al. 2011; Paoletti et al. 2015; Somlo et al. 2011).

VDR is a nuclear receptor and it is expected to demonstrate predominant positive nuclear localization. The expression of VDR among our breast cancer group exhibited cytoplasmic positivity $75.4 \%$ of the tissues, followed by both cytoplasmic and nuclear positivity in $21.5 \%$, and complete absence of staining in 3\% of specimen. There was no nuclear positivity only pattern observed among our study specimens. This was supported by The Malmö Diet and Cancer Study (MDCS) which showed a high percentage of intranuclear and cytoplasmic VDR expression in 718 invasive breast tumors (Huss et al. 2019). Another case-control study among inflammatory bowel disease patients and healthy control showed positive VDR expression was identified in both the nuclear and cytoplasmic components of the colonic epithelium (Abreu-Delgado et al. 2016). In breast cancer cells, an experimental study showed that cytoplasmic accumulation of VDR promotes in vitro growth of cancer cells (Trivedi et al. 2017).

A drawback of our work is that it was a casecontrol study which is susceptible to selection bias. The participants in the control group are younger and not age-matched to the control. However, despite the age difference, many research showed no variation in vitamin D level in different age groups (Deckers et al. 2013; dos Santos Ferreira et al. 2017; Waldhoer et al. 2018). Our study also did not consider the amount of sunlight exposure, as well as dietary intake of vitamin D rich foods or supplements which may affect the individual serum vitamin D level. The number of breast cancer patients was small which may govern the result of analysis stratified by hormonal receptor status.

TABLE 1. Age and serum 25-hydroxyvitamin D level of breast cancer patients and healthy subjects $(\mathrm{N}=142)$

\begin{tabular}{|c|c|c|c|}
\hline Characteristics & Breast cancer patients $(\mathrm{N}=69)$ & Healthy subjects $(\mathrm{N}=73)$ & P-value \\
\hline Age, years, mean (SD) & $54.58(12.03)$ & $32.71(7.64)$ & $<0.001$ \\
\hline $\begin{array}{l}\text { Serum } 25 \text {-hydroxyvitamin } \mathrm{D}, \mathrm{ng} / \mathrm{mL} \text {, } \\
\text { mean (SD) }\end{array}$ & $13.36(6.98)$ & $13.05(3.71)$ & 0.74 \\
\hline
\end{tabular}

P-value were determined by independent $t$-test. Significant at $\mathrm{p}<0.05$ 
TABLE 2. Vitamin D status of breast cancer patients and healthy subjects $(\mathrm{N}=142)$

\begin{tabular}{|c|c|c|c|c|c|}
\hline \multirow{2}{*}{ Characteristics } & \multicolumn{2}{|c|}{ Breast cancer patients $(\mathrm{N}=69)$} & \multicolumn{2}{|c|}{ Healthy subjects $(\mathrm{N}=73)$} & \multirow{2}{*}{ P-value } \\
\hline & Frequency & Percentage & Frequency & Percentage & \\
\hline Vitamin D status & & & & & 0.012 \\
\hline - $\quad$ Sufficient $(\geq 20 \mathrm{ng} / \mathrm{mL})$ & 10 & $14.5 \%$ & 2 & $2.7 \%$ & \\
\hline - $\quad$ Insufficient $(<20 \mathrm{ng} / \mathrm{mL})$ & 59 & $85.5 \%$ & 71 & $97.3 \%$ & \\
\hline
\end{tabular}

Note. P-value were determined by Chi-squared test. Significant at $\mathrm{p}<0.05$

TABLE 3. Serum 25(OH)D concentration in breast cancer patients by hormonal receptor and VDR expression

\begin{tabular}{|c|c|c|}
\hline Characteristics & Serum $25(\mathrm{OH}) \mathrm{D}, \mathrm{ng} / \mathrm{mL}$, mean $(\mathrm{SD})$ & P-value \\
\hline \multicolumn{3}{|l|}{ ER status } \\
\hline - $\mathrm{ER}+(\mathrm{N}=45)$ & $12.22(6.76)$ & 0.032 \\
\hline - $\quad$ ER- $(\mathrm{N}=23)$ & $16.01(6.68)$ & \\
\hline \multicolumn{3}{|l|}{ PR status } \\
\hline - $\quad \mathrm{PR}+(\mathrm{N}=40)$ & $12.13(6.83)$ & 0.050 \\
\hline - $\quad$ PR- $(\mathrm{N}=28)$ & $15.46(6.70)$ & \\
\hline \multicolumn{3}{|l|}{ HER2/C-ERB2 } \\
\hline - $\quad$ HER2/C-ERB2+ $(\mathrm{N}=27)$ & $13.08(8.03)$ & 0.686 \\
\hline - $\quad \mathrm{HER} 2 / \mathrm{C}-\mathrm{ERB} 2-(\mathrm{N}=41)$ & $13.78(6.18)$ & \\
\hline \multicolumn{3}{|l|}{ Triple negative } \\
\hline - $\quad$ Yes $(\mathrm{N}=11)$ & $17.04(5.69)$ & 0.064 \\
\hline - $\quad$ No $(\mathrm{N}=57)$ & $12.82(6.97)$ & \\
\hline \multicolumn{3}{|l|}{ VDR expression } \\
\hline - $\quad$ VDR+ & $13.75(6.86)$ & 0.659 \\
\hline - VDR- & $12.99(7.02)$ & \\
\hline
\end{tabular}

Standard deviation (SD). Estrogen receptor (ER). Progesterone receptor (PR). Vitamin D receptor (VDR). P-value were determined by independent $t$-test. Significant at $\mathrm{p}<0.05$ 
TABLE 4. Characteristics of breast cancer patients by VDR expression status

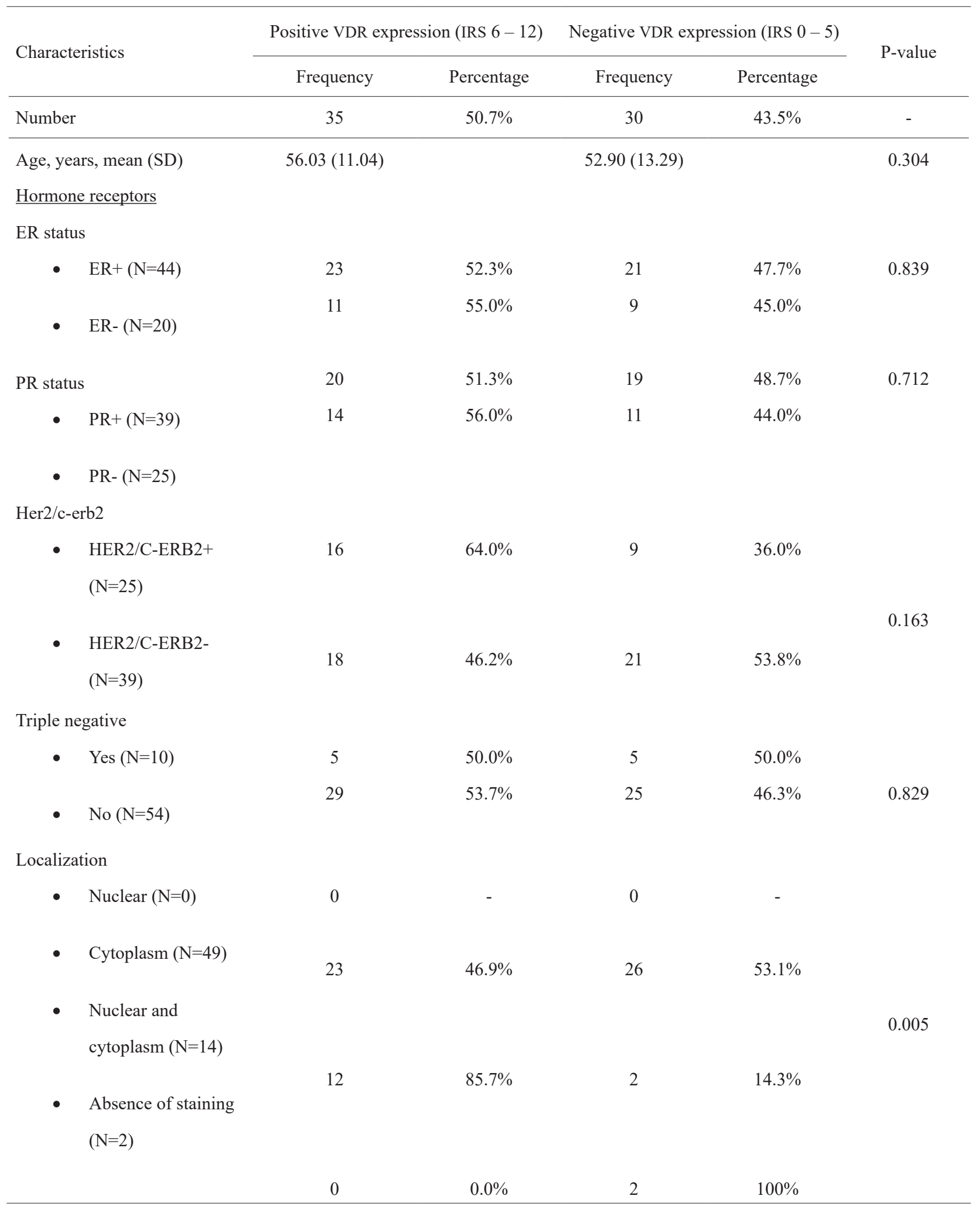

Estrogen receptor (ER). Progesterone receptor (PR). Vitamin D receptor (VDR). The p-values for age was determined by independent t-test, ER, PR, HER2 status and triple negative were based on Chi-squared test and for site was determined by Fisher's exact test. Significant at $\mathrm{p}<0.05$ 


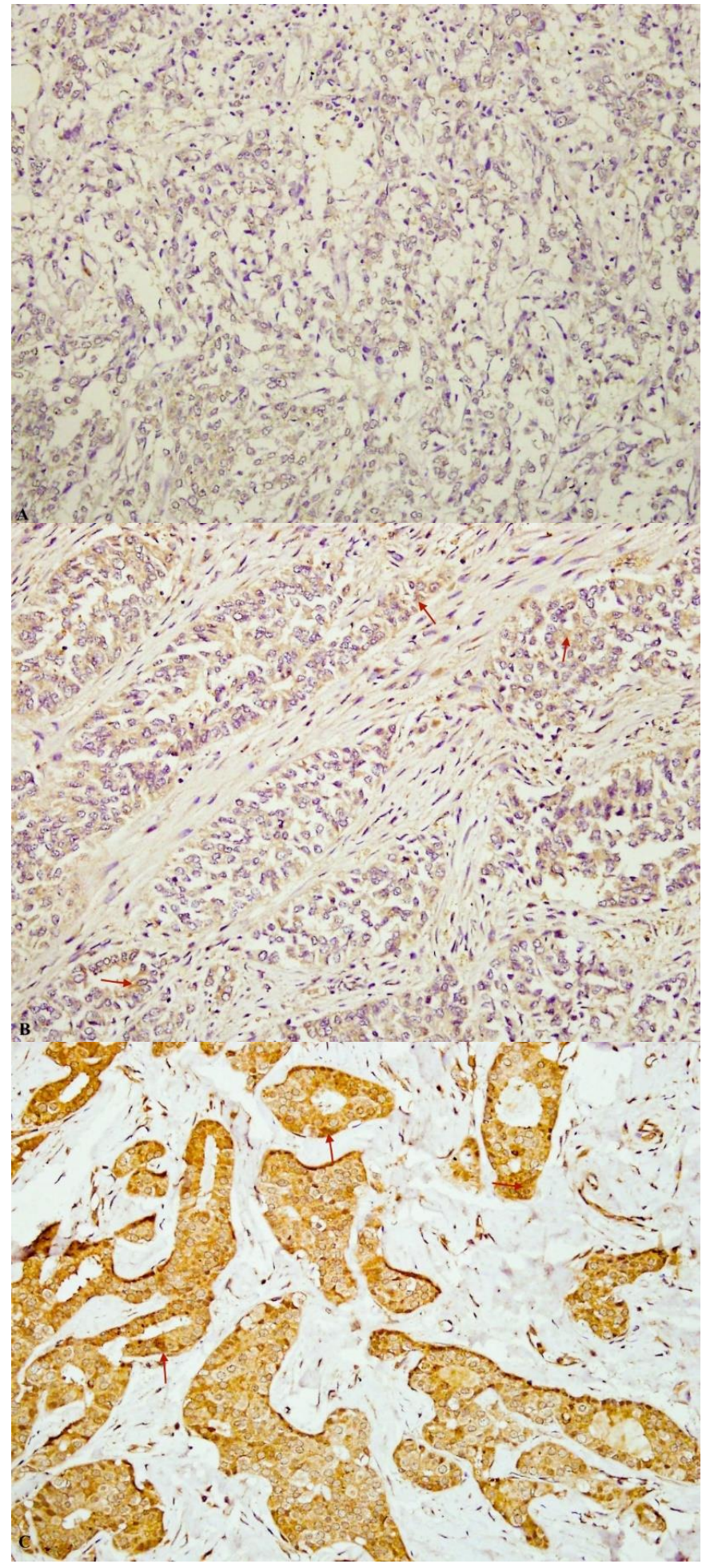




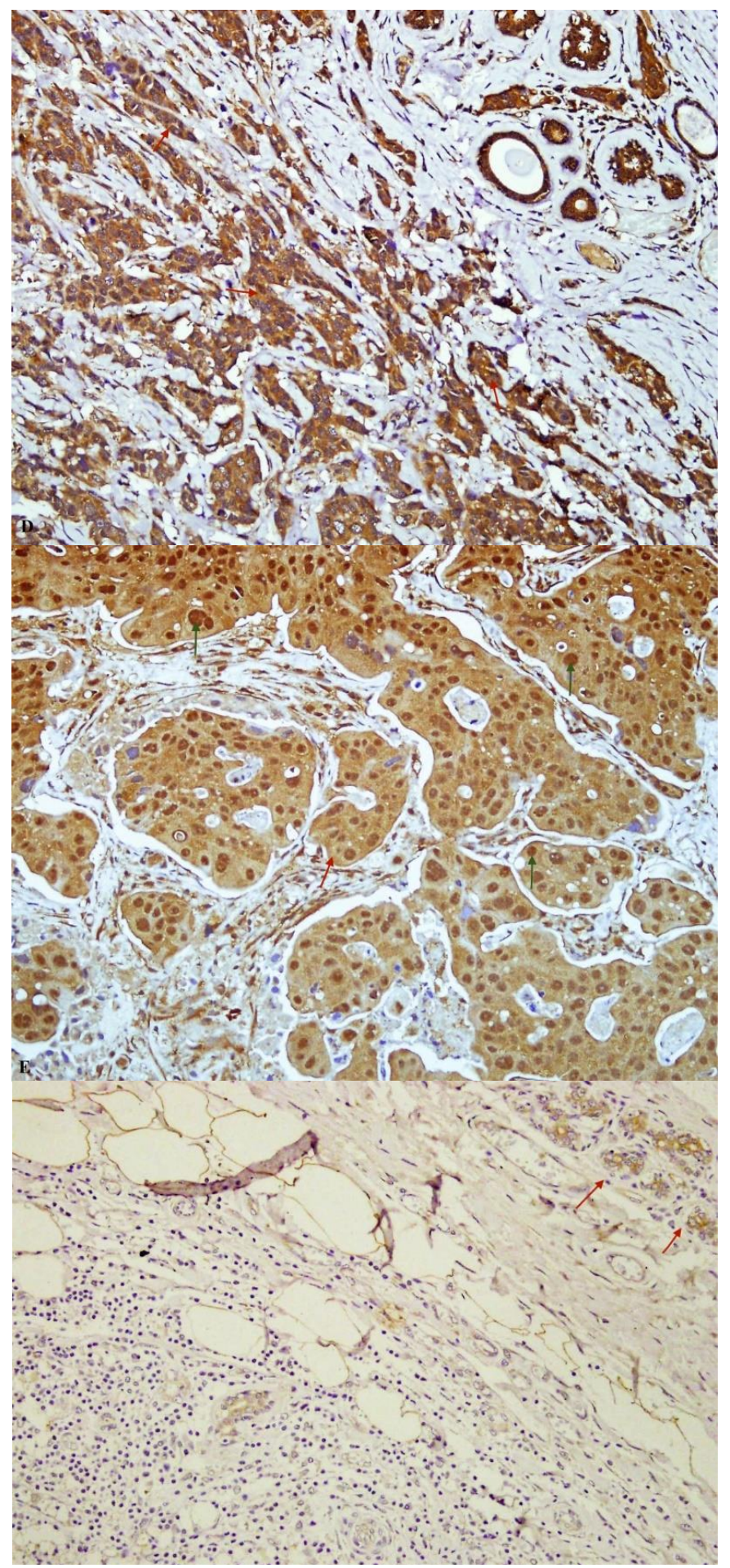

FIGURE 1. Immunohistochemistry test for Vitamin D Receptor in breast cancer tissue.

(A) Absence of staining, $\times 200$, (B) Weak cytoplasmic staining intensity, $\times 200$, (C)

Moderate cytoplasmic staining intensity, $\times 200$, (D) Strong cytoplasmic staining intensity, $\times 200$, (E) Nuclear and cytoplasmic positivity, $\times 200$, and (F) Arrows showed positive cytoplasmic VDR expression in adjacent normal breast tissue gland, in which acted as an internal positive control, $\times 100$ 


\section{CONCLUSION}

In conclusion, there was a high proportion of vitamin D deficiency among breast cancer patients and healthy volunteers in our study. Our study found no significant association between breast cancer and vitamin $\mathrm{D}$. There was a significant association between serum vitamin D level with ER and PR status. We also reported positive VDR expression in $50.7 \%$ of breast cancer tissue which is similar to the normal population. Perhaps there are various risk factors other than vitamin D level and its receptor expression that predispose to breast cancer development.

\section{ACKNOWLEDGEMENTS}

This work was supported by Pusat Pengajian Sains Perubatan (PPSP) Incentive Postgraduate Studies Development Fund (TIPPS) 2018. We thank Breast Cancer Awareness \& Research Unit (BestaRi), Hospital Universiti Sains Malaysia staff for assistance.

\section{REFERENCES}

Abreu-Delgado, Y., Isidro, R.A., Torres, E.A., Gonzalez, A., Cruz, M.L., Isidro, A.A., Gonzalez-Keelan, C.I., Medero, P. \& Appleyard, C.B. 2016. Serum vitamin D and colonic vitamin $\mathrm{D}$ receptor in inflammatory bowel disease. World J. Gastroenterol. 22(13): 3581-3591. doi.org/10.3748/wjg. v22.i13.3581.

Acevedo, F., Perez, V., Perez-Sepulveda, A., Florenzano, P., Artigas, R., Medina, L. \& Sanchez, C. 2016. High prevalence of vitamin D deficiency in women with breast cancer: The first Chilean study. Breast 29: 39-43. doi.org/10.1016/j. breast.2016.06.022

Aktas, B., Muller, V., Tewes, M., Zeitz, J., Kasimir-Bauer, S., Loehberg, C.R., Rack, B., Schneeweiss, A. \& Fehm, T. 2011. Comparison of estrogen and progesterone receptor status of circulating tumor cells and the primary tumor in metastatic breast cancer patients. Gynecol. Oncol. 122(2): 356-360. doi. org/10.1016/j.ygyno.2011.04.039.

Allred, D.C., Bustamante, M.A., Daniel, C.O., Gaskill, H.V. \& Cruz, A.B. 1990. Immunocytochemical analysis of estrogen receptors in human breast carcinomas: Evaluation of 130 cases and review of the literature regarding concordance with biochemical assay and clinical relevance. Archives of Surgery 125(1): 107-113. doi.org/10.1001/ archsurg.1990.01410130113018.

Azizah, AbM., Nor Saleh, I.T. \& Noor Hashima, A. 2016. Malaysian National Cancer Registry Report 2007-2011. Malaysia Cancer Statistics, Data and Figure. National Cancer Institute, Ministry of Health, Putrajaya, Malaysia.

Bandera Merchan, B., Morcillo, S., Martin-Nunez, G., Tinahones, F.J. \& Macias-Gonzalez, M. 2017. The role of vitamin D and VDR in carcinogenesis: Through epidemiology and basic sciences. The Journal of Steroid Biochemistry and Molecular Biology 167: 203-218. doi.org/10.1016/j. jsbmb.2016.11.020.

Binkley, N., Dawson-Hughes, B., Durazo-Arvizu, R. Thamm, M., Tian, L., Merkel, J.M., Jones, J.C., Carter, G.D. \& Sempos, C.T. 2017. Vitamin D measurement standardization: The way out of the chaos. The Journal of Steroid Biochemistry and Molecular Biology 173: 117-121.

Cashman, K.D., Dowling, K.G., Škrabáková, Z., Kiely, M., Lamberg-Allardt, C., Durazo-Arvizu, R.A., Sempos, C.T., Koskinen, S., Lundqvist, A. \& Sundvall, J. 2015. Standardizing serum 25-hydroxyvitamin D data from four Nordic population samples using the Vitamin D standardization program protocols: Shedding new light on vitamin D status in Nordic individuals. Scandinavian Journal of Clinical and Laboratory Investigation 75(7): 549-561.

Czogalla, B., Deuster, E., Liao, Y., Mayr, D., Schmoeckel, E., Sattler, C., Kolben, T., Hester, A., Fürst, S. \& Burges, A. 2020. Cytoplasmic VDR expression as an independent risk factor for ovarian cancer. Histochemistry and Cell Biology 154(4): 421-429.

de La Puente-Yagüe, M., Cuadrado-Cenzual, M.A., CiudadCabañas, M.J., Hernández-Cabria, M. \& Collado-Yurrita, L. 2018. Vitamin D: And its role in breast cancer. The Kaohsiung Journal of Medical Sciences 34(8): 423-427.

de Sousa Almeida-Filho, B., De Luca Vespoli, H., Pessoa, E.C., Machado, M., Nahas-Neto, J. \& Nahas, E.A.P. 2017. Vitamin D deficiency is associated with poor breast cancer prognostic features in postmenopausal women. The Journal of Steroid Biochemistry and Molecular Biology 174: 284289. doi.org/10.1016/j.jsbmb.2017.10.009.

Deckers, M.M.L., De Jongh, R.T., Lips, P.T.A.M., Penninx, B.W.J.H., Milaneschi, Y., Smit, J.H., van Schoor, N.M., Blankenstein, M.A. \& Heijboer, A.C. 2013. Prevalence of vitamin D deficiency and consequences for PTH reference values. Clinica Chimica Acta 426: 41-45. doi.org/10.1016/j. cca.2013.08.024.

Ditsch, N., Toth, B., Mayr, D., Lenhard, M., Gallwas, J., Weissenbacher, T., Dannecker, C., Friese, K. \& Jeschke, U. 2012. The association between vitamin D receptor expression and prolonged overall survival in breast cancer. Journal of Histochemistry \& Cytochemistry 60(2): 121129.

dos Santos Ferreira, C.E., Maeda, S.S., Batista, M.C., LazarettiCastro, M., Vasconcellos, L.S., Madeira, M., Soares, L.M., Borba, V.Z.C. \& Moreira, C.A. 2017. Consensus-reference ranges of vitamin D [25 $(\mathrm{OH}) \mathrm{D}]$ from the Brazilian medical societies. Brazilian Society of Clinical Pathology/ Laboratory Medicine (SBPC/ML) and Brazilian Society of Endocrinology and Metabolism (SBEM). Jornal Brasileiro de Patologia e Medicina Laboratorial 53(6): 377-381. doi. org/10.5935/1676-2444.20170060. 
Foong Ming Moy, Victor CW Hoe, Noran Naqiah Hairi, Shireene Ratna Vethakkan, \& Awang Bulgiba. 2017. Vitamin D deficiency and depression among women from an urban community in a tropical country. Public Health Nutrition 20(10): 1844-1850.

Holick, M.F. 2017. The vitamin D deficiency pandemic: Approaches for diagnosis, treatment and prevention. Rev. Endocr. Metab. Disord. 18(2): 153-165. doi.org/10.1007/ s11154-017-9424-1.

Holick, M.F., Binkley, N.C., Bischoff-Ferrari, H.A., Gordon, C.M., Hanley, D.A., Heaney, R.P., Murad, M.H., Weaver, C.M. \& Society Endocrine. 2011. Evaluation, treatment, and prevention of vitamin D deficiency: An endocrine society clinical practice guideline. J. Clin. Endocrinol. Metab. 96(7): 1911-1930. doi.org/10.1210/jc.2011-0385.

Huss, L., Butt, S.T., Borgquist, S., Elebro, K., Sandsveden, M., Rosendahl, A. \& Manjer, J. 2019. Vitamin D receptor expression in invasive breast tumors and breast cancer survival. Breast Cancer Research 21(1): 1-13.

Iqbal, B.M. \& Buch, A. 2016. Hormone receptor (ER, PR, HER2/neu) status and proliferation index marker (Ki67) in breast cancers: Their onco-pathological correlation, shortcomings and future trends. Medical Journal of Dr. DY Patil University 9(6): 674. doi.org/10.4103/09752870.194180.

Jacobs, E.T., Kohler, L.N., Kunihiro, A.G. \& Jurutka, P.W. 2016. Vitamin D and colorectal, breast, and prostate cancers: A review of the epidemiological evidence. Journal of Cancer 7(3): 232-240.

Jamila Al-Azhri, Yali Zhang, Wiam Bshara, Gary Zirpoli, Susan E McCann, Thaer Khoury, Carl D Morrison, Stephen B Edge, Christine B Ambrosone \& Song Yao. 2017. Tumor expression of vitamin D receptor and breast cancer histopathological characteristics and prognosis. Clinical Cancer Research 23(1): 97-103.

Jeon, S.M. \& Shin, E.A. 2018a. Exploring vitamin D metabolism and function in cancer. Exp. Mol. Med. 50(4): 20. doi. org/10.1038/s12276-018-0038-9.

Kondov, B., Milenkovikj, Z., Kondov, G., Petrushevska, G., Basheska, N., Bogdanovska-Todorovska, M., Tolevska, N. \& Ivkovski, L. 2018. Presentation of the molecular subtypes of breast cancer detected by immunohistochemistry in surgically treated patients. Open Access Macedonian Journal of Medical Sciences 6(6): 961-967.

Lalitha Palaniveloo, Yong Heng Yaw, Zalilah Mohd Shariff, Loh Su Peng, Jacques Bindels, Yvonne Yee Siang Tee \& Eline M van der Beek. 2020. Vitamin D status is associated with high BMI, working status and gravidity among pregnant Malaysian women. Malaysian Journal of Nutrition 26(1): 129-139.

Momenimovahed, Z. \& Salehiniya, H. 2019. Epidemiological characteristics of and risk factors for breast cancer in the world. Breast Cancer: Targets and Therapy 11: 151.

O’Brien, K.M., Sandler, D.P., Taylor, J.A. \& Weinberg, C.R. 2017. Serum vitamin D and risk of breast cancer within five years. Environmental Health Perspectives 125(7): 077004.
Omalkhair Abulkhair, Ahmed Saadeddin, Olaa Makram, Ahmed Gasmelseed, Tabrez Pasha, Hussam Shehata \& Hana M Fakhoury. 2016. Vitamin D levels and breast cancer characteristics: Findings in patients from Saudi Arabia. The Journal of Steroid Biochemistry and Molecular Biology 164: 106-109.

Paoletti, C., Muniz, M.C., Thomas, D.G., Griffith, K.A., Kidwell, K.M., Tokudome, N., Brown, M.E., Aung, K., Miller, M.C., Blossom, D.L., Schott, A.F., Henry, N.L., Rae, J.M., Connelly, M.C., Chianese, D.A. \& Hayes, D.F. 2015. Development of circulating tumor cell-endocrine therapy index in patients with hormone receptor-positive breast cancer. Clin. Cancer Res. 21(11): 2487-2498. doi.org/10.1158/1078-0432.CCR14-1913.

Pike, J.W., Meyer, M.B., Lee, S-M., Onal, M. \& Benkusky, N.A. 2017. The vitamin D receptor: Contemporary genomic approaches reveal new basic and translational insights. The Journal of Clinical Investigation 127(4): 1146-1154.

Ross, A.C., Taylor, C.L., Yaktine, A.L. \& Del Valle, H.B. 2011. Dietary reference intakes for calcium and vitamin D. In Institute of Medicine (US) Committee to Review Dietary Reference Intakes for Vitamin D and Calcium. Washington: National Academies Press. Accessed on 2 January 2016.

Scarmo, S., Afanasyeva, Y., Lenner, P., Koenig, K.L., Horst, R.L., Clendenen, T.V., Arslan, A.A., Chen, Y., Hallmans, G., Lundin, E., Rinaldi, S., Toniolo, P., Shore, R.E. \& ZeleniuchJacquotte, A. 2013. Circulating levels of 25-hydroxyvitamin D and risk of breast cancer: A nested case-control study. Breast Cancer Res. 15(1): R15. doi.org/10.1186/bcr3390.

Soljic, M., Mrklic, I., Tomic, S., Omrcen, T., Sutalo, N., Bevanda, M. \& Vrdoljak, E. 2018. Prognostic value of vitamin D receptor and insulin-like growth factor receptor 1 expression in triple-negative breast cancer. Journal of Clinical Pathology 71(1): 34-39. doi.org/10.1136/ jclinpath-2016-204222.

Somlo, G., Lau, S.K., Frankel, P., Hsieh, H.B., Liu, X., Yang, L., Krivacic, R. \& Bruce, R.H. 2011. Multiple biomarker expression on circulating tumor cells in comparison to tumor tissues from primary and metastatic sites in patients with locally advanced/inflammatory, and stage IV breast cancer, using a novel detection technology. Breast Cancer Research and Treatment 128(1): 155-163. doi.org/10.1007/ s10549-011-1508-0.

Statistics on Causes of Death, Malaysia. 2018. https://www.dosm. gov.my/v1/index.php?r=column/pdfPrev\&id=aWg2VjJkZH hYcDdEM3JQSGloeTV1Zz09.

Stepman, H.C.M., An Vanderroost, Van Uytfanghe, K. \& Thienpont, L.M. 2011. Candidate reference measurement procedures for serum 25-hydroxyvitamin D3 and 25-hydroxyvitamin D2 by using isotope-dilution liquid chromatography-tandem mass spectrometry. Clinical Chemistry 57(3): 441-448. doi. org/10.1373/clinchem.2010.152553.

Thienpont, L.M., Stepman, H.C.M. \& Vesper, H.W. 2012. Standardization of measurements of 25-hydroxyvitamin D3 and D2. Scand. J. Clin. Lab Invest. Suppl. 243(sup243): 4149. doi.org/10.3109/00365513.2012.681950. 
Trivedi, T., Zheng, Y., Fournier, P.G.J., Murthy, S., John, S., Schillo, S., Dunstan, C.R., Mohammad, K.S., Zhou, H. \& Seibel, M.J. 2017. The vitamin D receptor is involved in the regulation of human breast cancer cell growth via a ligandindependent function in cytoplasm. Oncotarget 8(16): 26687 26701. doi.org/10.18632/oncotarget.15803.

Waldhoer, T., Endler, G., Yang, L., Haidinger, G., Wagner, O. \& Marculescu, R. 2018. Vitamin D deficiency, overall and cause-specific mortality: The impact of age. Revue d'Épidémiologie et de Santé Publique 66: S271. doi. org/10.1016/j.respe.2018.05.092.

Wise, S.A. \& Watters Jr., R.L. 2009. Certificate of Analysis Standard Reference Material 2975. Gaithersburg, MD.

Yao, S., Kwan, M.L., Ergas, I.J., Roh, J.M., Cheng, T-Y.D., Hong, C-C., McCann, S.E., Tang, L., Davis, W. \& Liu, S. 2017. Association of serum level of vitamin $\mathrm{D}$ at diagnosis with breast cancer survival: A case-cohort analysis in the pathways study. JAMA Oncology 3(3): 351-357. doi.org/10.1001/ jamaoncol.2016.4188.

Zhang, X., Hofmann, S., Rack, B., Harbeck, N., Jeschke, U. \& Sixou, S. 2017. Fluorescence analysis of vitamin d receptor status of circulating tumor cells (CTCS) in breast cancer: From cell models to metastatic patients. Int. J. Mol. Sci. 18(6): 1318. doi.org/10.3390/ijms18061318.

Hani Ajrina Zulkeflee, Tuan Salwani Tuan Ismail* \& Tengku Ahmad Damitri Al-Astani Tengku Din

Department of Chemical Pathology

School of Medical Sciences

Universiti Sains Malaysia

16150 Kubang Kerian, Kelantan Darul Naim

Malaysia

Maya Mazuwin Yahya

Department of Surgery

School of Medical Sciences

Universiti Sains Malaysia

16150 Kubang Kerian, Kelantan Darul Naim

Malaysia
Wan Faiziah Wan Abdul Rahman

Department of Pathology

School of Medical Sciences

Universiti Sains Malaysia

16150 Kubang Kerian, Kelantan Darul Naim

Malaysia

Tuan Salwani Tuan Ismail* Tengku Ahmad Damitri Al-Astani Tengku Din, Maya Mazuwin Yahya \& Wan Faiziah Wan Abdul Rahman

Hospital Universiti Sains Malaysia

16150 Kubang Kerian, Kelantan Darul Naim

Malaysia

Hani Ajrina Zulkeflee

Faculty of Medicine and Health Sciences

Universiti Sains Islam Malaysia

Bandar Baru Nilai

71800 Nilai, Negeri Sembilan

Malaysia

Tengku Ahmad Damitri Al-Astani Tengku Din \& Maya Mazuwin Yahya

Breast Cancer Awareness and Research Unit (BestaRi)

Hospital Universiti Sains Malaysia

16150 Kubang Kerian, Kelantan Darul Naim

Malaysia

*Corresponding author; email: tusti@usm.my

Received: 11 August 2020

Accepted: 15 March 2021 